\title{
ЭКОНОМИКО-МАТЕМАТИЧЕСКОЕ МОДЕЛИРОВАНИЕ ФОРМИРОВАНИЯ РАБОЧИХ МЕСТ
}

\author{
Агафонов А.A., \\ Золотова T.A., \\ Баскакова Ю.Л.
}

Сердобский филиал Пензенского государственного университета, г. Сердобск, Россия

Экономико-математические модели применяют с иелью отыскания лучшего решения. Моделирование рынка занятости и формирования рабочих мест на региональном уровне является актуальной задачей современной России.

Ключевые слова: рабочие места, рынок труда, математическое моделирование.

Формирование рынка занятости и создание рабочих мест является актуальной задачей в современной России. Именно на региональном уровне формируется концепция занятости, предусматриваются меры по стимулированию создания на предприятиях новых рабочих мест.

Основным обобщающим показателем, характеризующим эффективность производства, является показатель экономического эффекта $(E)$. Он определяется как разность между стоимостной оценкой осуществления нового производства за расчетный период $(P)$ и стоимостной оценкой затрат на осуществление нового производства за расчетный период $(Z)$ :

$$
E=P-Z
$$

Существует несколько методов оценки эффективности формирования нового производства. Сами критерии выбора могут быть связаны с определением максимума экономического эффекта или с минимизацией затрат на организацию производства. Сами условия применения расчетных формул связаны с конкретной ситуацией, в которой находится предприятие.

В настоящее время развитию регионов, бесспорно, способствует малое предпринимательство, которое является важным сектором экономики. Малый бизнес - это дополнительные рабочие места, производство продукции и оказание услуг, необходимых для нужд района, налоговые платежи в местный бюджет.

На территории Сердобского района Пензенской области зарегистрировано 731 субъект малого и среднего предпринимательства (на 01.01.2020 год). Наибольшая доля субъектов малого и среднего предпринимательства приходится на розничную торговлю, транспортные и бытовые услуги, общественное питание.

С целью создания благоприятных условий, обеспечивающих устойчивое развитие малого и среднего бизнеса на территории муниципального 
образования, разработана и реализуется муниципальная программа «Развитие и поддержка малого и среднего предпринимательства в городе Сердобске Сердобского района Пензенской области на 2014-2020 годы». В рамках программы осуществляется имущественная, консультационная и информационная поддержка субъектов предпринимательства. Но важным спектром развития любого предприятия является привлечение инвестиций.

Анализ финансового и экономического положения показал, что для расчета экономического эффекта можно использовать критерий максимизации эффективности:

$$
E=\left(\sum_{i=0}^{n} P_{i} \cdot c_{i}-\sum_{i=0}^{n} Q_{i} \cdot c_{i}\right) \rightarrow \max
$$

где, $P_{\mathrm{i}}$ - результат внедрения нового производства в $i$ - ом году (руб.);

$Q_{\mathrm{i}}$ - затраты на разработку, производство и использование нового производства в $i$ - ом году (руб.);

$c_{\mathrm{i}}-$ коэффициент приведения разновременных показателей;

$i=0$ - начальный год расчетного периода;

$i=n-$ конечный год расчетного периода;

При применении формулы (2) необходимо выполнение следующих условий:

- стоимостная оценка полезных результатов;

- данные о произведенных затратах за отчетные периоды;

- технико-экономические показатели за расчетные периоды.

Были произведены расчеты показателей по ряду предприятий, направленные на формирование новых рабочих мест, которые позволили спрогнозировать создание до 50 рабочих мест. Но в результате деятельности предприятий, некоторые вновь созданные рабочие места были аннулированы. Основными причинами этого явления стали: финансовая неустойчивость предприятий, социальная незащищенность рабочих и, как следствие, большая текучесть кадров. Предприятиям была оказана финансовая помощь, но в некоторых случаях она использовалась не по назначению. Что, в свою очередь, также привело к сокращению рабочих мест.

Для предотвращения подобных случаев необходимо более тщательно производить анализ возможностей предприятий по использованию финансовой поддержки. Для этого необходимо сформировать пакет документов, который будет содержать следующие показатели:

- проект организации рабочих мест, в котором сформулированы технико-экономические затраты (номенклатура, контингент, период занятости);

- финансовый отчет предприятия;

- обоснование спроса на продукцию, под которую планируется создание новых рабочих мест;

- расчет экономической эффективности капитальных вложений, направленных на создание социальной и экологической защищенности новых рабочих мест; 
- необходимость дополнительной подготовки и переподготовки кадров.

В августе 2019 года запущено производства полного цикла ООО «Грибная компания" на территории индустриального парка «Сердобский» в Сердобском районе Пензенской области. Проект реализован при поддержке ВТБ. Банк предоставил ООО «Грибная компания» инвестиционный кредит в размере 1,2 млрд. рублей на 8 лет в рамках государственной программы поддержки сельхозпроизводителей. Компания планирует реализовать проект по созданию высокотехнологичного агропромышленного комплекса грибного направления. В рамках проекта предусмотрено создание 162 новых рабочих мест, объем инвестиций составит около 1 миллиарда 250 млн. рублей.

Если производство работает при его реорганизации, то необходимо минимизировать остатки незавершенного производства, т.е., свести к минимуму колебания графика выпуска продукции. Экономико-математическая задача имеет вид:

$$
\begin{gathered}
L=\sum_{i=1}^{n}\left(x_{i}+c_{i}\right) \rightarrow \min \\
\left\{\begin{array}{c}
x_{i}-a_{i}-\left(b_{i}-b_{i-1}\right)=0 \\
x_{i+1}-x_{i}-c_{i}+d_{i}=0 \\
x_{i}, b_{i}, c_{i}, d_{i} \geq 0 \\
i=1, \ldots, n
\end{array}\right.
\end{gathered}
$$

где $x_{\mathrm{i}}$ - выпуск продукции в $i$-ом интервале является искомой величиной; $a_{\mathrm{i}}-$ спрос на продукцию; $b_{0}$ и $b_{\mathrm{n}}-$ начальный и конечный запасы продукции соответственно; $c_{\mathrm{i}}-$ прирост производства; $d_{\mathrm{i}}-$ снижение производства. Задача решается методами линейного программирования.

Анализ данного пакета документов позволит Инвестору осуществлять контроль над целевым использованием финансовых вложений и в дальнейшем, в качестве стимулирования, оказывать финансовую поддержку предприятиям на льготных условиях.

\section{Список литературы}

1. Глухов В.В., Медников М.Д., Коробко С.Б. Математические методы и модели для менеджмента. 2-е изд., испр. и доп. - СПб.: Издательство «Лань», 2005. $-528 \mathrm{c}$.

2. Саматова Т.Б., Оленькова Н.Б., Пономаренко Н.А. Методика оценки эффективности формирования новых рабочих мест // Проблемы освоения природных ресурсов Европейского Севера: сборник научных трудов. Ухтинский индустриальный институт. Ухта. 2004. С. 212-215.

3. Комплексный инвестиционный план модернизации города Сердобска на период 2010-2020 годы [Электронный ресурс]. - Режим доступа: http://www.pnzreg.ru/news/2016/10/7/16174786/print. 